\title{
A COMPARATIVE EXPERIMENTAL-MORPHOLOGICAL STUDY OF THE METHODS OF CHEMODESTRUCTION, CRYODESTRUCTION AND LASER DESTRUCTION OF THE PERIPHERAL NERVE TRUNK
}

\author{
M.F. Posokhov \\ Cand. Sci. (Med.), Docent, Head of the department \\ Department of Functional Neurosurgery with a group \\ of pathomorphology \\ "Institute of Neurology, Psychiatry and Narcology \\ of NAMS of Ukraine" State Institution \\ 46 Akademika Pavlova St., Kharkiv, 61068, Ukraine \\ tel: +38 (050) 677-77-53 \\ e-mail:nsd17@ukr.net \\ ORCID 0000-0003-3361-5522
}

\section{V.I. Tsymbalyuk}

Dr. Sci. (Med.), Prof., Academician of NAMS of Ukraine,

President of NAMS of Ukraine

SI "Romodanov Neurosurgery Institute of NAMS of Ukraine"

32 Platona Mayborody St., Kyiv, 04050, Ukraine

tel: +38 (044) 483-94-13

e-mail:neuro.kiev@gmail.com

ORCID 0000-0001-7544-6603

\author{
O.V. Gorbunov \\ Junior Researche \\ Department of Functional Neurosurgery with a group \\ of pathomorphology \\ "Institute of Neurology, Psychiatry and Narcology \\ of NAMS of Ukraine" State Institution \\ 46 Akademika Pavlova St., Kharkiv, 61068, Ukraine \\ tel: +38 (066) 374-68-05 \\ e-mail: o.gorbunov68@ukr.net \\ ORCID 0000-0002-6092-9925
}

An experimental morphological study of the methods of chemodestruction, cryodestruction and laser destruction as those of medical denervation in pharmacoresistant forms of prosopalgia was carried out. The obtained data testify to the presence of evident destructive macro- and microscopic changes both in the nerve trunk and its surrounding tissues when using alcoholic chemodestruction. A lesser degree of morphological changes was observed in phenol chemodestruction. Cryodestruction was characterized by morphological signs of persistent denervation with a minimal manifestation of perifocal changes in the surrounding tissues. The laser method of denervation resulted in replacement of destruction by regeneration in the early period. Perifocal changes were minimal.

Key words: pharmacoresistant prosopalgia, alcoholic chemodestruction, phenol chemodestruction, cryodestruction, laser destruction.

\section{ПОРІВНЯЛЬНЕ ЕКСПЕРИМЕНТАЛЬНО-МОРФОЛОГЧНЕ ВИВЧЕННЯ МЕТОДІВ ХЕМОДЕСТРУКЦІї, КРІОДЕСТРУКЦІї ТА ЛАЗЕРНОЇ ДЕСТРУКЦІї ПЕРИФЕРИЧНОГО НЕРВОВОГО СТОВБУРА}

М.Ф. Посохов ${ }^{1}$, О.В. Горбунов ${ }^{1}$, В.І. Цимбалюк ${ }^{2}$

${ }^{1}$ ДУ «Інститут неврологї̈, психіатрії та наркологї̈ НАМН України», м. Харків, Украӥна;

${ }^{2}$ ДУ«Інститут нейрохіруреї̈ ім. акад. А.П. Ромоданова НАМН Украӥни», м. Київ, Україна

Проведено експериментально-морфологічне вивчення методів хемодеструкції, кріодеструкції та лазерної деструкції, як методів лікувальної денервації при фармакорезистентних формах прозопалгій. Отримані дані свідчать про наявність виражених деструктивних макро- і мікроскопічних змін, як в нервовому стовбурі, так і в навколишніх тканинах при використанні алкогольної хемодеструкції. Менша ступінь вираженості морфологічних змін спостерігалася при феноловій хемодеструкції. Кріодеструкція характеризується морфологічними ознаками стійкої денервації при мінімальній вираженості перифокальних змін в оточуючих нерв тканинах. При лазерному способі денервації деструкція в ранні терміни змінюється регенерацією; перифокальні зміни наймінімальніші.

Ключові слова: фармакорезистентні прозопалгії, алкогольна деструкція, фенольна хемодеструкція, кріодеструкція, лазерна деструкція. 
СРАВНИТЕЛЬНОЕ ЭКСПЕРИМЕНТАЛЬНО-МОРФОЛОГИЧЕСКОЕ ИЗУЧЕНИЕ МЕТОДОВ ХЕМОДЕСТРУКЦИИ, КРИОДЕСТРУКЦИИ И ЛАЗЕРНОЙ ДЕСТРУКЦИИ ПЕРИФЕРИЧЕСКОГО НЕРВНОГО СТВОЛА

\author{
Н.Ф. Посохов ${ }^{1}$, О.В. Горбунов ${ }^{1}$, В.И. Цымбалюк ${ }^{2}$ \\ ${ }^{1}$ ГУ «Институт неврологии, психиатрии и наркологии Национальной Академии медицинских наук Украины», \\ 2. Харьков, Украина;

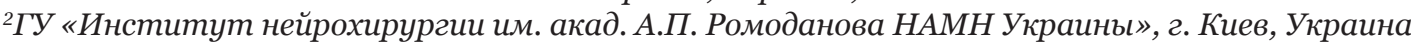

Проведено экспериментально-морфологическое изучение методов хемодеструкции, криодеструкции и лазерной деструкции, как методов лечебной денервации при фармакорезистентных формах прозопалгий. Полученные данные свидетельствуют о наличии выраженных деструктивных макро- и микроскопических изменений, как в нервном стволе, так и в окружающих тканях при использовании алкогольной хемодеструкции. Меньшая степень выраженности морфологических изменений наблюдалась при феноловой хемодеструкции. Криодеструкция характеризуется морфологическими признаками стойкой денервации при минимальной выраженности перифокальных изменений в окружающих нерв тканях. При лазерном способе денервации деструкция в ранние сроки сменяется регенерацией; перифокальные изменения самые минимальные.

Ключевые слова: фармакорезистентные прозопалгии, алкогольная деструкция, феноловая хемодеструкция, криодеструкция, лазерная деструкция.

\section{Introduction}

Pharmacoresistant facial pains (prosopalgias) belong to the most severe human pain syndromes [1-4]. Despite a rather large number of studies and publications, by now the problem of surgical treatment of patients with severe forms of prosopalgias remains urgent. Recent years have witnessed a tendency for a wide use of mini-invasive technologies for treatment of prosopalgias, including different transcutaneous puncture methods for destructing facial nerve formations.

Historically and practically, the following methods of puncture destruction have become the most common ones:

- alcoholization (alcoholic chemodestruction), introduced into clinical practice by C. Schlősser in 1903 [5];

- electrocoaglulation, suggested by Kirschner M. in 1932 [6];

- phenol chemodestruction, suggested by Jefferson A. in 1963 and widely used worldwide by now $[7,8]$;

- hydrothermal destruction of the trigeminal ganglion and sensory root, developed by Jaeger R. in 1954 and improved by Livshitz L.Ya. in 1965 [9];

- cryodestruction (cryoneurotomy) of the sensory root and peripheral branches of the trigeminal nerve (Sipitiy V.I., Posokhov M.F., 1984) [10-12];

- radiofrequency destruction (Cosman E.R. et al., 1984) [13];

- laser destruction (Kozel A.I., 1996; Posokhov M.F., Chernenkov V.G., Pykhtin A.V., 2010) [14-17].

Prominent among the above listed ways are puncture methods of chemodestruction used for treating severe forms of trigeminal neuralgia. Of them, the most widespread is the method of alcoholization; it was introduced into clinical practice by Schlősser C. in 1903 and for a long period of time regarded as mini-invasive, technically simple and effective $[5,18]$. It was believed that alcoholization of peripheral branches "seldom produces complications, does not require hospitalization of the patient, has no contraindications and can be repeated in recurrences...”. Alcoholization was considered as "... a chemical section of the nerve by means of aseptic necrosis leading to an interruption of conductivity and, consequently, discontinuation of pain attacks, followed by regeneration of the peripheral nerve owing to anatomical integrity of its coats" [19]. According to findings of the study, conducted by Shengeliya N.Sh. on a high electronic microscopic level, alcoholization develops "the required degree of nerve degeneration, providing a stable disturbance of innervation" [20].

Nevertheless despite a long time period of its use and efficacy in providing emergency care the result of the treatment was always controversial. Clinical observations showed that remission after the first alcoholization lasted from a few weeks to 3 years, as a rule, with a subsequent recurrence of pains. The effect of each subsequent alcoholization decreased and was accompanied by the development of an evident cicatricial adhesion (it making repeated manipulations more difficult) in the perineural tissues and "iatrogenic neuritis of branches" or, in the modern interpretation, degenerative-dystrophic changes in fibres of the peripheral branches of the trigeminal nerve, thereby, as it turned out, neutralizing the effect of treatment. It was not in rare cases that repeated alcoholizations were followed by a stable pain syndrome with an atypical clinical picture $[21,22]$. Nevertheless alcohol-novocaine blocks, as an emergency care for controlling severe facial pain syndrome, have been used up to now.

The methods of chemodestruction include the method of phenol blocks with phenol injections into the trigeminal nerve, ganglion and trigeminal cavity (Jefferson A., 1963; Vasin N.Ya., 1973) [7,8]. Here the ability of phenol to cause coagulation of protein with 
resultant denervation is used. But phenol is a poisonous substance, it requiring a very precise dosage. This method has not become widely used in our country, nevertheless abroad it came into use long ago [23,24].

Also used is the method of injection of glycerin into the trigeminal cistern, when within 4 years after the manipulation pain recurrences were observed in $18-31 \%$ of cases too [25].

At different times other methods of nerve destruction were suggested, in particular those connected with the effect of a high temperature, such as: the method of electrocoagulation suggested by Kirschner M. in 1932 and the method of hydrothermal destruction of the trigeminal ganglion and sensory nerve developed by Jaeger R. in 1954 and Livshitz L.Ya. in 1965 $[6,9,26,27]$. These methods also gave only a temporary interruption of pains, with a high percentage of complications and recurrences of pains. Vasin N.Ya. presented in his publication the following statistical data: from 2,358 electrocoagulations there were up to $2 \%$ with painful anaesthesias, $9 \%$ with keratitis and $25 \%$ with recurrences; in 350 patients with a directed hydrothermal destruction $5.3 \%$ of cases developed keratitis and 8.1\% had pain recurrences, reference to Livshitz L.Ya.; in 1,870 patients with alcoholizations there were $13 \%$ with keratitis and $29 \%$ with recurrences [8].

The method of electrocoagulation did not demonstrate any significant advantages over alcoholization because of a poorly controlled and unregulated depth of destruction [28]. The performance of electrocoagulation was followed by formation of a connective tissue cicatrix in the traumatic damage area and by formation of true neuromata $[29,30]$. The performance of hydrothermal destruction resulted in such complications as neuroparalytic keratitis, meningism, meningitis, pain dysesthesia and lesion of other cranial nerves owing to a poorly controlled and unregulated depth of destruction and other effects of physical action on the nerve tissue as well as on the adjacent tissues caused by "fluidity" of solutions and their penetration outside the trigeminal sinus. Modern literature data vary enormously. According to Troyan V.V., the above-mentioned complications after hydrothermal destruction of the trigeminal nerve were revealed in $70.6 \%$ of patients [31]. But according to data of other authors, temporary phenomena of facial dysesthesia after hydrothermal destruction developed only in $8.2 \%$ of cases, and no other above-mentioned postoperative complications were observed [32].

Recently the method of low-temperature destruction - selective cryoneurotomy or cryodestruction (Sipitiy V.I., Posokhov M.F., 1984) - and the method of laser destruction (Kozel A.I., 1996; Posokhov M.F., Chernenkov V.G., Pykhtin A.V., 2010) were suggested $[10,11,12,14,15,33,34]$.

The preference of cryodestruction is confirmed by duration of its effect (the pain scale) and values of the life quality, as it is reported by many authors. The use of cryodestruction is an effective and pathogenetically substantiated method with resultant stable neurodynamic phenomena and inhibition of pathological nociceptive input. Here a local cryoinfluence on the nerve does not form any connective tissue cicatrix [10,15].

The method of laser destruction of the trigeminal nerve has not been sufficiently studied. At present the literature on laser destruction contains findings of some authors about formation of a cicatrix in the nerve trunk in case of the surgical laser way of denervation (on an example of using a neodymium laser with a wavelength of $1,064 \mathrm{~nm}$ ), it contradicting to our experimental data obtained with use of a semiconductor laser with a wavelength of $980 \mathrm{~nm}[15,16,17,35]$.

The present literature describes advantages and disadvantages of different puncture methods of destruction. There are no publications in the available literature that would comparatively generalize morphological changes after using different techniques of destruction. In this connection we have conducted an experimental research for studying morphological changes in nerve trunks and surrounding tissues after application of the most commonly used neurosurgical methods for destruction of peripheral nerves that is necessary for optimizing the choice of methods of treatment.

The use of mini-invasive methods of puncture destruction of the peripheral nerve trunk (chemodestruction, cryodestruction and laser destruction) presupposes certain peculiarities of its regeneration, which more or less correspond to the ultrastructural organization of the nerve in each destruction variant, it being important prognostically [36,37]. We associate pathological kinds of regeneration with pain recurrences and development of atypical pains that apparently has a morphological basis.

The complete reparative regeneration of a damaged nerve trunk in compliance with its morphology must include: elimination of degeneration consequences, stimulation of the growth of axons, stimulation of the process of myelination of the newly formed axons including activation of the synthetic and proliferative activity of Schwann cells and differentiation of the myelin coat formed, excluding at the same time cicatrization and formation of neuromata $[38,39,40]$.

The purpose of the present research was to carry out a comparative experimental study of peculiarities of morphological changes in the peripheral nerve trunk and its surrounding tissues in dynamics after: chemodestruction with alcohol and $5 \%$ phenol solution in glycerin, cryodestruction and surgical laser destruction.

\section{Materials and methods}

Alcoholization, chemodestruction with phenol solution in glycerin, cryodestruction and laser destruction of the sciatic nerve in outbred male rats were chosen as a model for the experimental study.

The experimental studies were conducted with observation of international and Ukrainian laws on 
65 four-month-old white Wistar male rats with the initial body weight of 250-300 g. Two control (9 animals) and four experimental groups with 14 animals in each were formed. Animals from control group I were not subjected to any surgical intervention, but served for studying the normal anatomical and histological structure. Animals from control group II underwent only surgical approaches without destruction of the nerve. Here the sciatic nerve tissue in the surgical approach region was sutured throughout. The term of 30 days revealed an area of a local myelin destruction (demyelination) in the sutured region owing to the development of foreign body granulomata with presence of typical multinucleate giant cells of "foreign bodies" around the suture material (Fig 2, b,c).

Animals from the experimental groups underwent different kinds of destruction of their sciatic nerve: alcoholic hemodestruction (group I), phenol chemodestruction (group II), cryodestruction (group III) and laser destruction (group IV).

The operations were performed under general anaesthesia by an intraperitoneal injection of 2.8-3.6 ml of $0.5 \%$ solution of sodium thiopental (14-18 mg per $1 \mathrm{~kg}$ of the animal body weight).

In order to carry on the experiment, the rat sciatic nerve was chosen, as its ultrastructural organization on the whole is close to the structure of peripheral branches in the human trigeminal nerve. The choice of rats as experimental animals was determined by a possibility to have an easy surgical approach to their sciatic nerve and a possible technical objectification of the size of the damaged region.

A double showering of the surgical field with $70 \%$ alcohol and $2 \%$ iodine alcohol solution was followed by a 20-25 mm linear incision of the skin and subcutaneous fat on the posterior surface in the middle third of the thigh. The sciatic nerve was bluntly separated and then destructed (Fig 1, $a, b, c$ ) by means of:

- an endoneural injection of $0.1 \mathrm{ml}$ of $95 \%$ ethanol (animals from experimental group I);

- an endoneural injection of $0.1 \mathrm{ml}$ of $5 \%$ phenol solution in glycerin (experimental group II);
- cryodestruction with help of a cryoprobe (B. Verkin Institute for Low Temperature Physics and Engineering of the National Academy of Sciences of Ukraine), $1.2 \mathrm{~mm}$ in diameter, with a temperature of the cooled tip $-70^{\circ} \mathrm{C}$ during 60 seconds (animal group III);

- laser destruction using continuous laser radiation with a wavelength of $980 \mathrm{~nm}$, a radiation power of $3 \mathrm{~W}$ and a radiation dose of $50 \mathrm{~J}$ (experimental group IV). "Lika-Surgeon" semiconductor laser (Fotonika Plus private small manufacturing company, Cherkasy, Ukraine) was used as the source of laser radiation.

After the required operative procedure the wound was completely closed. During their postoperative period the animals were followed up in dynamics. Attention was paid to: behaviour of the animals; the state of their postoperative wound, which every day was treated with $1 \%$ methylene green solution; presence of macroscopic changes on the posterior surface of the thigh and the whole extremity; presence and degree of manifestation of neurologic disorders. Diaries of the ethological monitoring of the animals were kept.

The rats were removed from the experiment on days $1,3,7,14,21,30$ and 60 by overdosage of sodium thiopental at a dose of $30 \mathrm{mg}$ per $1 \mathrm{~kg}$ of body weight (1.2-1.6 $\mathrm{ml}$ of $0.5 \%$ solution). The state of the nerve and paraneural tissues was studied macro- and microscopically (using a binocular magnifying glass with a fibre-optic illuminator providing 3.5-fold magnification) and specimens were taken for a histological examination. The tissue of the damaged nerve and adjacent tissues (muscles, connective tissue) were studied as a single block.

The following histological staining techniques were used: haematoxylin-eosin (review methodology), according to Van Gieson (on connective tissue elements, collagen), according to Nissl (nerve fibres, cell nuclei), silvering according to Bilshovsky (nerve fibres, axons), on myelin according to Krutsay (makes it possible to reveal myelin and all structural components of a nerve fibre) [41]. We believe that the morphological

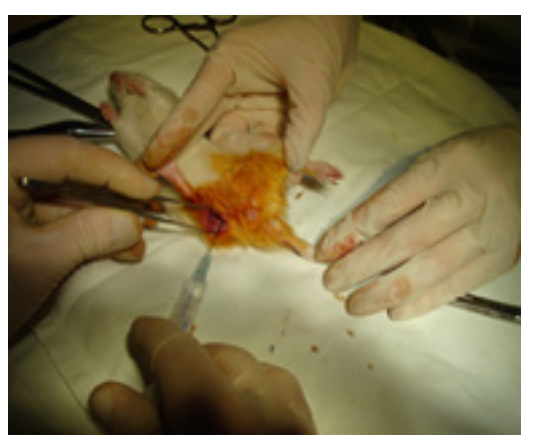

a)

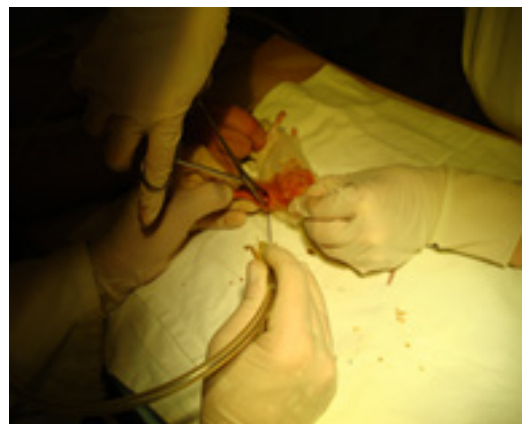

b)

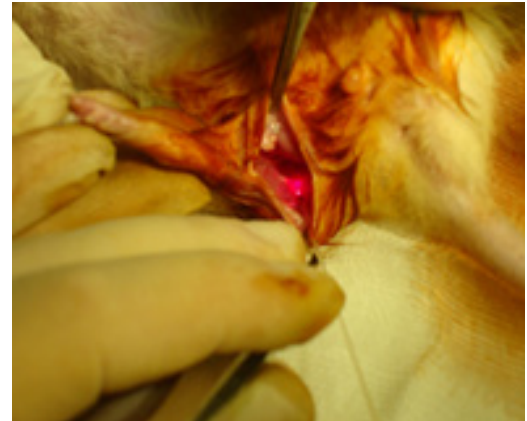

c)

Fig.1. Kinds of surgical interventions:

chemodestruction (groups I-II) (a); cryodestruction (group III) (b); laser destruction (group IV) (c) 
techniques, which were used before and presented in a number of researches, are not sufficiently informative.

The following morphological changes served as criteria for assessing the state of the structural-functional organization of the nerve in the area of destruction: degree of manifestation of destructive changes, depth of destruction, intensity (taking into account the character and intensity of damages of myelin coats and axial cylinders (axons) of nerve fibres, degree of damaging of connective tissue elements and Schwann cells, including cell nuclei), character and prevalence of inflammatory cell reactions, rates of normalization of the nerve fibre structure.

\section{Results and discussion}

An aetiological observation over animals from experimental group I showed that their injection was followed by: sluggishness of the animals during all the terms of their follow-up, inhibition of food and behavioural reflexes, formation of massive inflammatory infiltrates in the wound with the subsequent formation of rough connective tissue cicatrices in the perineural tissues, presence of trophic disturbances on the lower extremity with different degrees of their manifestation according to the damaged region.

A macromicroscopic study of the region of alcoholization of the sciatic nerve in rats within 1-3 days of their follow-up revealed appearance of prominent oedema with numerous haemorrhages as well as leukocyte infiltration in the perineural tissues and nerve trunk with a relative preservation of the anatomical integrity of the outer connective tissue coat (perineurium) of the sciatic nerve. During this period the nerve trunk developed necrobiosis with prevalence of intrafibrous oedema, swelling, twisting and fragmentation of axial cylinders (axons) as well as a myeloarchitectural disorder in the form of nerve fibre myelin degradation (Fig. 3, a).

The term of 3-7 days revealed massive leukocyte infiltration in the perineural tissues (Fig. 3, b), followed within 7-21 days by proliferation of connective tissue elements with formation of a connective tissue cicatrix and collagenization (Fig 3, c, $d, e$ ).

The study of the nerve trunk structure on day 60 after alcoholization found presence of a severe lesion of axons, Schwann cells and their nuclei and death of most of Schwann cell nuclei in the nerve trunk. The changes in the nerve could be characterized as "neuropathy": only single preserved nuclei or small chains of nuclei along nerve fibres were seen, large balloon vacuolation of myelin coats of nerve fibres prevailed and almost a total death (degradation) of axons was observed (Fig. 3,e); the perineural tissues contained a connective tissue cicatrix. Signs of "pathological” regeneration were observed on day 60 following alcoholization of the sciatic nerve in one case. Compensatory reinnervation was in the form of growth of two axons at once in a poorly preserved endoneural tube (Fig. 3, f).
Complete regeneration, as judged by the changes, was problematic (the changes were irreversible).

An aetiological observation over animals from experimental group II revealed a long-term inhibition of their food and behavioural reflexes too (up to 30 days) as well as presence of prominent pain manifestations within the postoperative period, a long-term healing of surgical wounds and, in some cases, presence of trophic disturbances on the sole skin and peculiar putrid-like changes in muscles apparently resulting from the general toxic effect of phenol.

A macroscopic examination of the nerve trunk and paraneural tissues in animal group II during 1-3 days called attention to preservation of the anatomical integrity of the outer connective tissue coat (perineurium) of the sciatic nerve. Here the nerve trunk was locally thickened.

A microscopic study of the dynamics of destructive processes in the region of performed chemodestructon demonstrated that the region of phenolization in the nerve trunk within the early period (1-3 days) revealed intrafibrous oedema, swelling, signs of fragmentation of axial cylinders (axons) in combination with destruction of myelin coats up to fine granular disintegration, a sharp wrinkling of Schwann cell nuclei and their pale staining with haematoxylin-eosin (Fig. 4, a). From the first day a moderately marked leukocyte infiltration in the tissues, which surrounded the nerve, was present.

The period of 3-7 days after chemodestruction conducted with phenol solution in glycerin revealed actually similar morphological changes in the nerve trunk and surrounding tissues with prevalence of phenomena of destruction of axons and myelin in the form of their granular disintegration with preservation of Schwann cell nuclei.

Within the term from days 14 to 21 , round cell infiltration was preserved in the tissues surrounding the nerve with preservation of wrinkling of Schwann cell nuclei, but some nuclei were clearer stained. Against a background of the observed fragmentation and granular disintegration of the most of axial cylinders and myelin already there was formation of outer myelin coats of fibres with signs of the beginning of clearing of the endoneural tubes from breakdown products by macrophages and without any signs of axon regeneration (Fig. 4, b).

The term of 30 days after chamodestruction revealed a decrease of cell infiltration and oedema in the surrounding tissues; the sciatic nerve contained longitudinally oriented Schwann cells (in the form of "bands"), which created contours of the endoneural tubes; it was possible to observe clearing of the endoneural tubes from breakdown products of axons and myelin coats and small-bubble vacuolation in myelin (apparently, activation of the endoplasmic reticulum of Schwann cells).

At the term of 60 days after the surgical intervention the nerve contained longitudinally oriented 
endoneural tubes, formed by bands of Schwann cells, which in their turn formed new myelin coats; the newly formed myelin coats demonstrated small-bubble vacuolation (activation of the endoplasmic reticulum); there was no oedema, but moderate sclerotic changes in the tissues surrounding the nerve were present. The nuclei of Schwann cells were expanded; the newly formed axons were thin and sparse. Growth flasks were seen; these were single and very sluggish (Fig. 4, c).

An aetiological observation over operated animals from experimental group III revealed absence of evident pain manifestations within all terms of their follow-up, a rapid healing of surgical wounds, an absolute absence of infectious complications and trophic disturbances, a high ability of the animals to restore their general motor functions as well as rapid restoration of food and behavioural reflexes (days 4-5).

A macroscopic study of the region of cryodestruction within the first day called attention to preservation of the anatomical integrity of the outer connective tissue coat (perineurium) of the sciatic nerve. The nerve trunk was locally thickened.

A microscopic study of the dynamics of destructive and reparative processes in the region of cryodestruction registered an almost total absence of the exudate component and leukocyte infiltration in tissues within the early terms (days 1-3). The nerve trunk had: intrafibrous oedema, swelling, signs of twisting and focal fragmentation of axial cylinders (axons) - cryogenic necrobiosis with peculiar "tears" of the protoplasm in axial cylinders, destruction of myelin coats and swelling of Schwann cell nuclei (Fig. 5, a).

The period of 3-7 days after cryodestruction revealed an increase of the intrafibrous oedema, the region of destruction actually spreading all over the nerve (the cryoinjury region). The nerve fibres were locally thickened and swollen, the vessels were paretically dilated and ischemic, Schwann cells and their nuclei were swollen, myelin coats were in the state of degradation, the axial cylinders were swollen, fragmented, twisting and in some places thickened with "tears". There was no leukocyte infiltration in the tissues.

The period of days 14-21 was characterized by a decreased oedema and absence of leukocyte infiltration, meanwhile the nerve demonstrated fragmentation and granular disintegration of the most of axial cylinders and myelin, the endoneural tubes and Schwann cell nuclei being partially intact on microscopy.

The term of 30 days after cryodestruction revealed absence of cell infiltration and oedema in the surrounding tissues and the nerve itself; longitudinally oriented bands of Schwann cells were visualized in the sciatic nerve, the structure of nerve fibres showing granular disintegration of the most of axial cylinders (axons) and myelin coats with elimination of their fragments (Fig. 5, b).

The term of 60 days after cryodestruction demonstrated absence of oedema in the surrounding tissues, but moderate sclerotic changes were present. Only longitudinally oriented bands of Schwann cells were visualized in the nerve against a background of a total absence of signs of axon regeneration after granular disintegration of axial cylinders and myelin coats and a total elimination of their fragments. Microscopically, no signs of activation of the endoplasmic reticulum in the form of fine granular vacuolation, like in group II, were present (Fig. 5, c).

An observation over animals from experimental group IV after their exposure to laser radiation revealed absence of evident pain manifestations, a rapid restoration of food and behavioural reflexes, a rapid healing of surgical wounds, a high ability of the animals to restore motor functions in their extremities, absence of subsequent trophic skin disturbances and a total absence of infectious complications.

A morphological study at the term of 1 day after the use of laser destruction found presence of a local narrow circular area of high-temperature coagulation in the epineurium with thickening of the tissues (Fig. 6, a). An exposure to laser resulted in focal demyelization or coagulation in myelin coats of nerve fibres ("bald patches" in myelin), twisting and fragmentation of axial cylinders (axons) with preservation of Schwann cells and their nuclei and the anatomical integrity of the nerve trunk (Fig. 6, $a, b$ ).

Within days 7-14 after laser destruction the nerve fibre structure revealed "cleaning" macrophages against a background of prevailing processes of disintegration in the form of fragmentation and granular axon disintegration with preservation of the structure of the endoneural tubes and Schwann cell nuclei (Fig. 6, c).

The period of days 21-30 after laser destruction demonstrated signs of an increased metabolic activity with a peculiar small-bubble "vacuolation" in myelin coats (well seen on a cross section of the fibres) that in combination with a darker (versus the first 1-3 days) staining of myelin is considered by us as remyelination or restoration of the structure of myelin (Fig. 6, $d$ ).

By day 60 after laser destruction the restoration of the nerve fibre structure was observed: the fibre contours were clear, small-bubble vacuolation was preserved in some places of myelin coats, and growth of axons was observed in the endoneural tubes with formation of "growth flasks" (Fig. 6, e, f).

The dynamics of destructive and reparative processes in the perineural tissues, studied by us, showed that the focus of laser destruction within the early term (days 1-3) revealed a very poor manifestation rate of the exudate component and leukocyte infiltration, the subcutaneous fat contained minor bleedings, there was a moderate oedema and, in some vessels, margination. A gradual resolution of the bleedings and a reduction of leukocyte infiltration were observed on days 3-7 of the study.

An examination of connective tissue elements (fibroblasts) of the tissues surrounding the nerve showed 


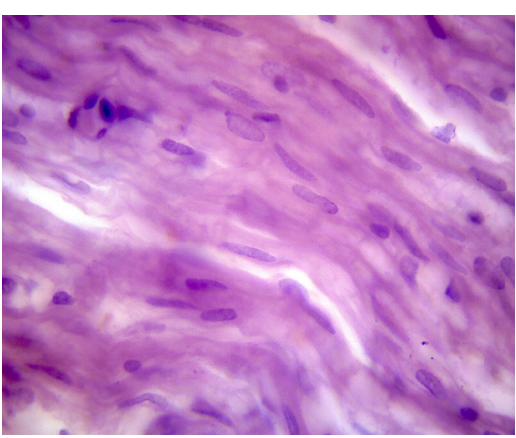

a)

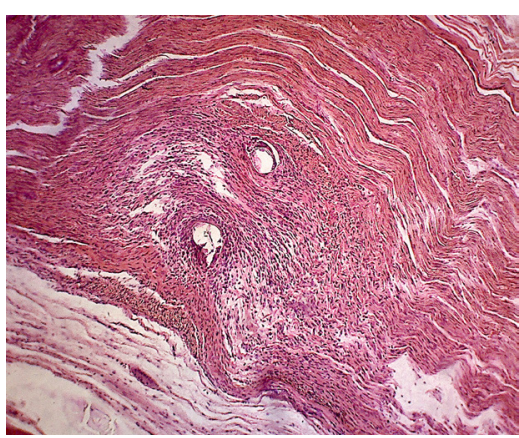

b)

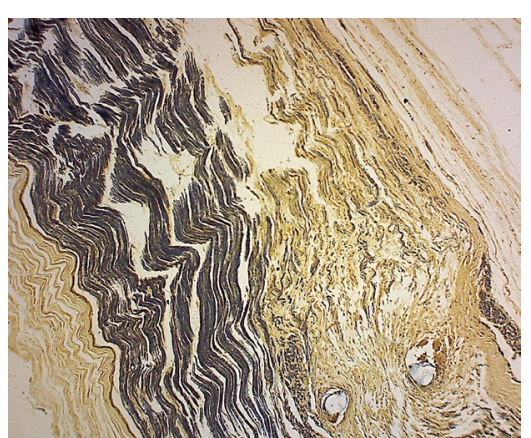

c)

Fig. 2. Control study (microslides):

H\&E stain. MAGN × 1000 (a); H\&E stain. MAGN × $100($ b); Krutsay's stain. MAGN × 100 (c)

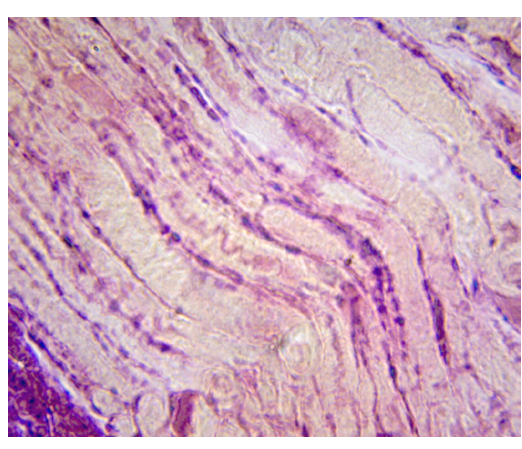

a)

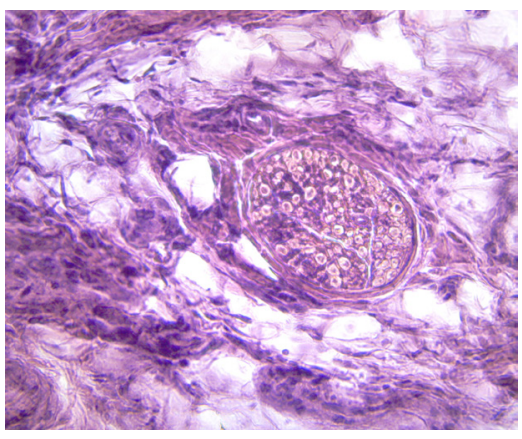

d)

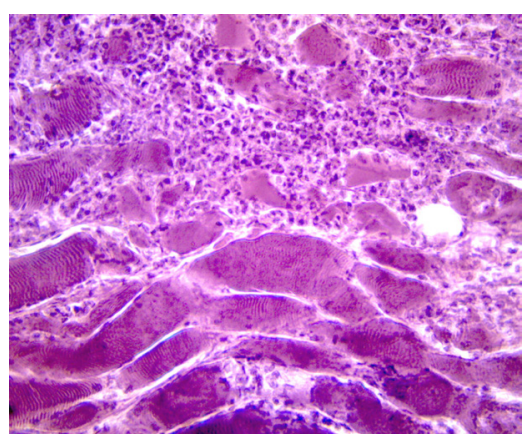

b)

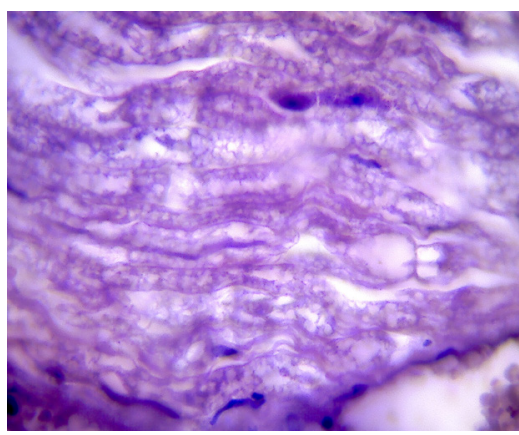

e)

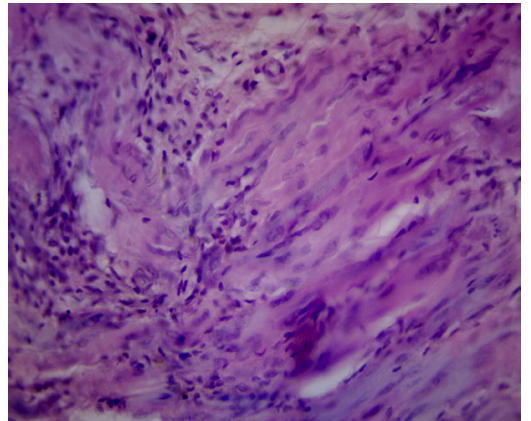

c)

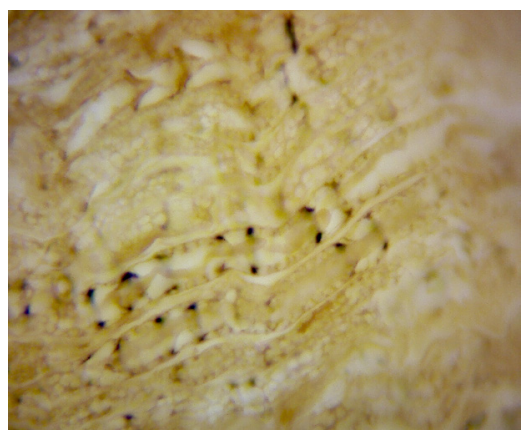

f)

Fig. 3. Alcoholization of the nerve (microslides):

Day 1. H\&E stain. MAGN $\times 1000$ (a); Day 7. H\&E stain. MAGN $\times 400(b)$; Day 14. H\&E stain. MAGN $\times 400(c)$; Day 21. H\&E stain. MAGN $\times 400($ d); Day 60. H\&E stain. MAGN $\times 1000(e)$; Day 60. Krutsay's stain. MAGN $\times 1000(f)$

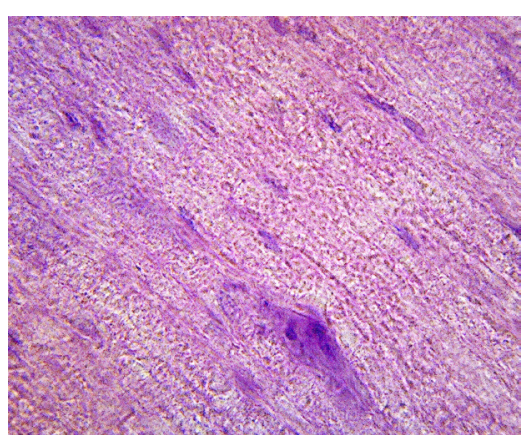

a)

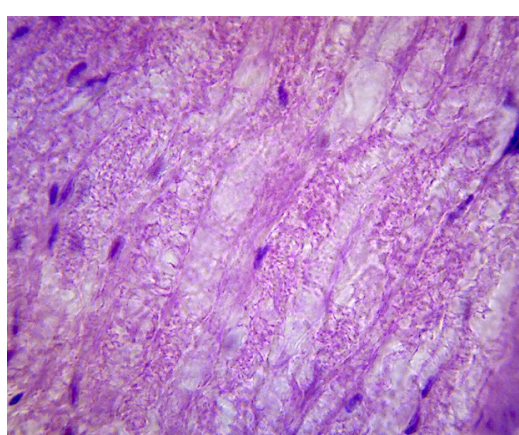

b)

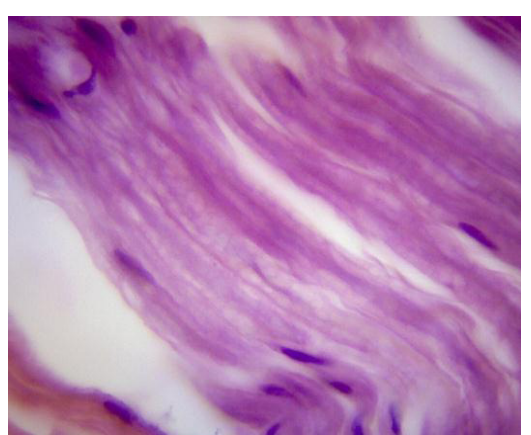

c)

Fig. 4. Phenolization of the nerve (microslides):

Day 1. H\&E stain. MAGN $\times 1000$ (a); Day 21. H\&E stain. MAGN $\times 1000$ (b); Day 60. H\&E stain. MAGN $\times 1000(c)$ 


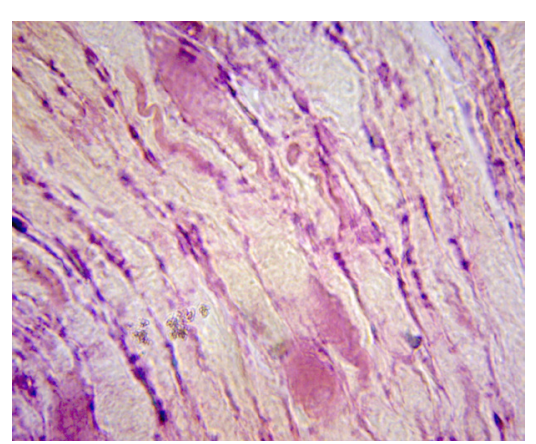

a)

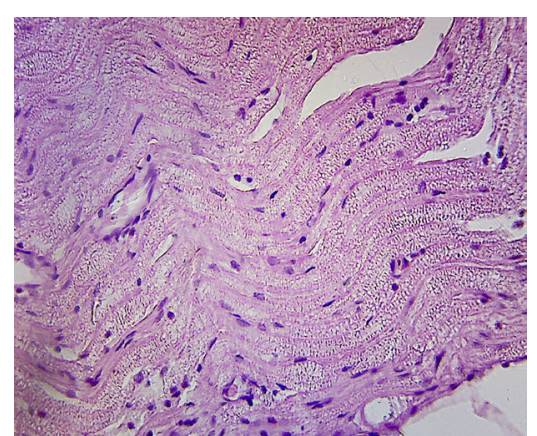

b)

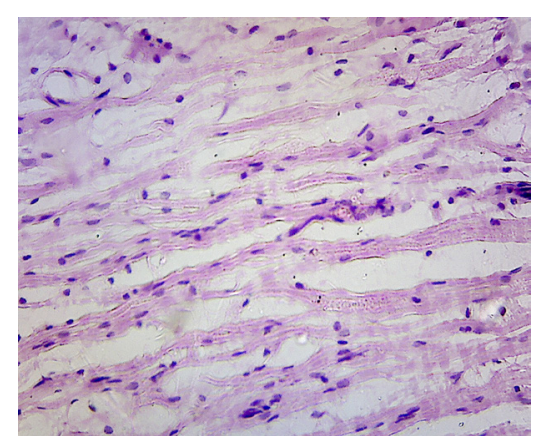

c)

Fig. 5. Cryodestruction of the nerve (microslides):

Day 1. H\&E stain. MAGN $\times 900$ (a); Day 30. H\&E stain. MAGN $\times 400($ b); Day $60 . H \& E$ stain. MAGN $\times 400(c)$

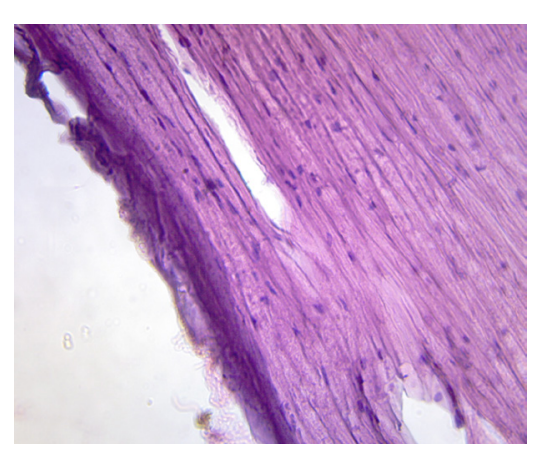

a)

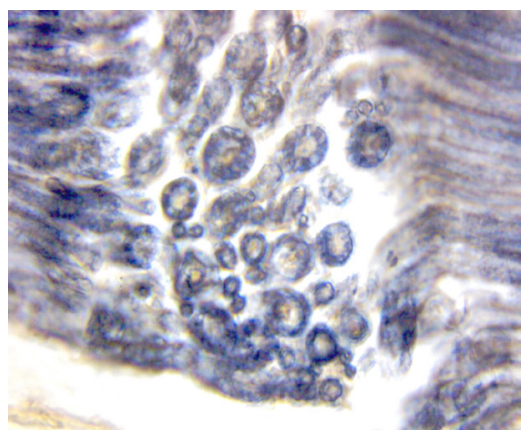

d)

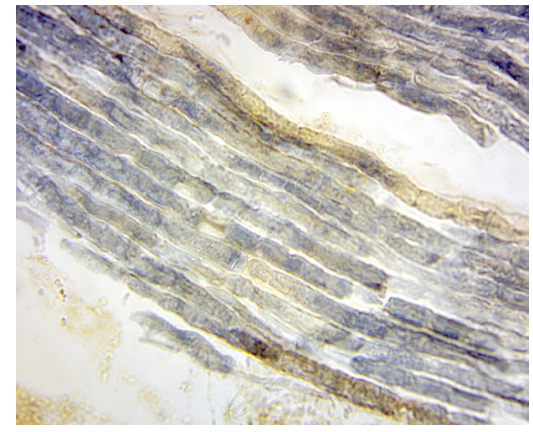

b)

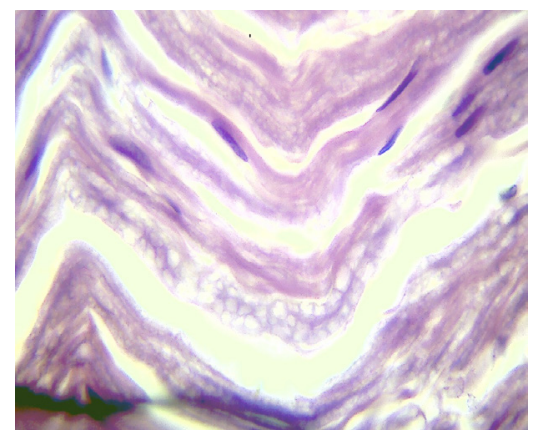

e)

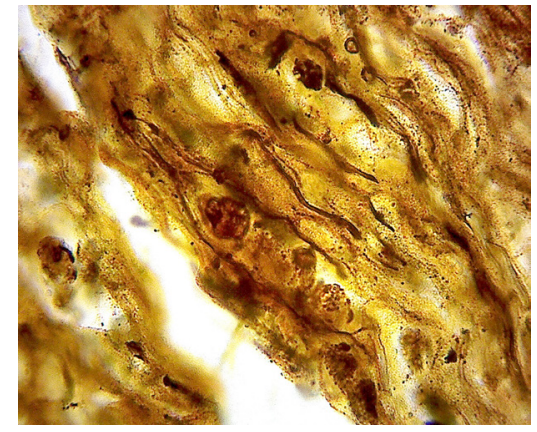

c)

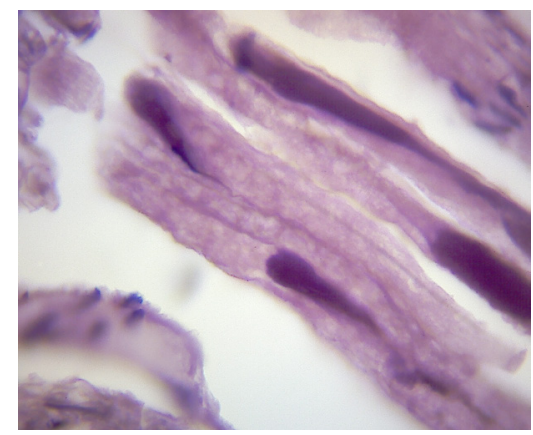

f)

Fig. 6. Laser destruction of the nerve (microslides):

Day 1. H\&E stain. MAGN $\times 400$ (a); Day 1. Krutsay's stain. MAGN $\times 400(b)$; Day 7. Bilshovsky's stain. MAGN $\times 1000(c)$; Day 30. Krutsay's stain. MAGN ×900 (d); Day 60. H\&E stain. MAGN ×900 (e); Day 60. H\&E stain. MAGN ×1000 (f)

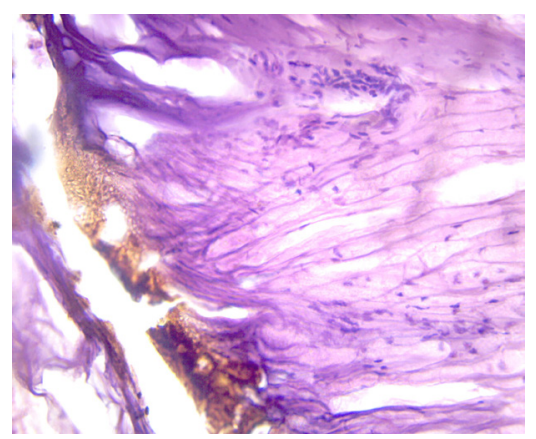

a)

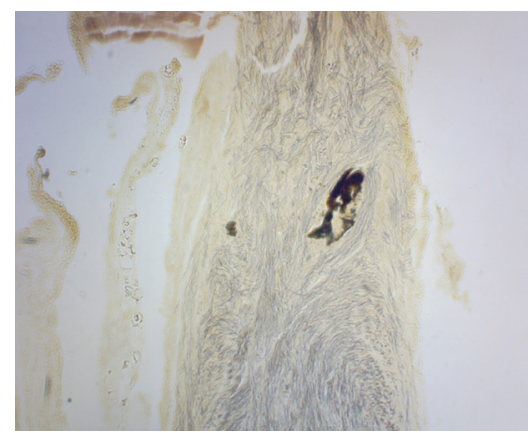

b)

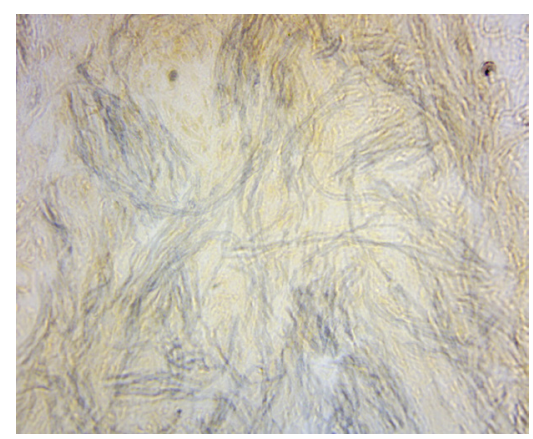

c)

Fig. 7. Laser neurotomy (microslides)):

Day 1. H\&E stain. MAGN $\times 900$ (a); Day 30. Krutsay's stain. MAGN ×100 (b); Day 30. Krutsay's stain. MAGN × 1000 (c) 
their moderate proliferative activity from days $6-7$ and to the end of the experiment without development of rough collagen cicatrices. A thickening of myofibrils (consequences of protein coagulation) was observed in muscular fibres at different terms.

In some cases (with a change in the radiation dosage) laser neurotomy was experimentally obtained. At the term of 1 day the nerve trunk revealed a transversal area of neurotomy with marginal coagulation, the adjacent nerve fibres being oedematous-swollen (Fig. 7, $a$ ).

After 30 days following laser neurotomy, regeneration of axial cylinders (axons) in the nerve stump was seen; large magnification revealed elongated twisted axons (a chaotic growth) without accompanying proliferation of Schwann cells, thereby setting this structure apart from neuromata (Fig. 7, $b, c$ ).

According to findings of our study, certain morphological peculiarities in the regeneration of the sciatic nerve of rats in each kind of destruction were found out.

After alcoholization, the preservation of the anatomical integrity of connective tissue coats of the nerve per se, if judged by results of the study, did not provide favourable conditions for regeneration because of damage of nuclei of specialized Schwann cells. Phenomena of only a partial restoration of some damaged axial cylinders and absence of a total restoration of the structure of axons and myelin by the end of day 60 of the follow-up were registered. The development of evident pathomorphological changes was observed, both in the nerve trunk in the form of "neuropathy" and in the surrounding tissues in the form of a marked cicatrization, the morphological changes being irreversible. From the morphological viewpoint, alcoholic chemodestruction should be included into traumatic methods of denervation. The method of peripheral alcoholization gives only a temporary effect, which decreases with each subsequent manipulation. This method causes gross degenerative changes in fibres of the trigeminal nerve and often results in the appearance of a persistent pain syndrome in the clinical practice.

The performance of chemodestruction of the nerve trunk with $5 \%$ phenol solution in glycerin was followed by necrobiosis with disintegration of axons (axial cylinders) and fragmentation of myelin coats of nerve fibres with preservation of the macroanatomy of the nerve trunk and Schwann cell nuclei; there was neither prominent leukocyte infiltration within the early terms nor evident cicatrization in the tissues within the remote terms (60 days). By day 60 after chemodestruction of the nerve, phenomena of regeneration with a partial restoration of myelin coats and a growth of axons (reversibility of the changes) were observed. In view of the registered general toxic effect of phenol a more prudent approach to using this method of treatment in patients with severe forms of facial pains is required.

Cryodestruction of the nerve trunk developed a low-temperature necrobiosis with demyelination of the coats and fragmentation of axial cylinders (axons) of nerve fibres with preservation of the macroanatomy of the nerve trunk and preservation of Schwann cell nuclei with the adjacent area of the Schwann cell. Disintegration of myelin coats of nerve fibres and axons provided a persistent interruption of conductance along the nerve trunk. Cryodestruction preserved the anatomical tubular structure of the perineurium and endoneurium, with preservation of Schwann cells in the form of Büngner bands and preservation of Schwann cell nuclei within 60 days that, as we believe, should in future provide favourable conditions for regeneration and restoration of the nerve structure.

The findings of our research demonstrate absence of leukocyte infiltration within the early terms and cicatrization within the remote terms (up to 60 days) in the perineural tissues after cryodestruction of the nerve. By day 60 after the cryosurgical operation, a persistent denervation without any signs of axon regeneration within that term was observed. The above makes it possible to say about advantages of the cryosurgical method of destruction of nerve trunks, which gives a theoretical basis for developing new methods for treatment of prosopalgias on the basis of cryosurgical technologies.

Laser destruction of the nerve trunk in the chosen mode resulted in lysis of myelin coats and fragmentation of axial cylinders (axons) of nerve fibres with preservation of the nerve trunk macroanatomy and Schwann cell nuclei. Disintegration of myelin coats of nerve fibres and axons provided a persistent interruption of conductance along the nerve trunk. In some cases of laser neurotomy (transection of the nerve trunk) the remote period (60 days) revealed a chaotic growth of axons through the region of neurotomy (the latter, as it turned out, was not an obstacle for that), but without any proliferation of Schwann cells, signs of formation of neuromata and cicatricial changes. In this connection an idea appeared that it would be possible to suture the nerve after a preliminary laser treatment of the damaged nerve areas with an expectant minimization of cicatricial changes.

A possible achievement of a high energy density with a precise dosage of radiation power per unit of the tissue volume enabled us to receive a well-controlled region of a local influence with the minimal heating and deformity of the adjacent tissue areas, it being similar to laser welding (and cutting) in engineering. We observed creation of fixed joints by making interatomic bonds between the welded parts (in our case, damaged edges of Schwann cells). The effect of the laser beam energy on the biological tissue resulted in a sharp increase of temperature in its limited region, achieving about $400^{\circ} \mathrm{C}$ in the "irradiated" place. Since a width of the focused bundle was about $0.01 \mathrm{~mm}$, the heat spread over a very small area. As a result of such a punctate effect of a high temperature the irradiated area was instantly burnt down, partially evaporating. 
Thus laser irradiation caused coagulation of proteins of a live tissue, transfer of the tissue fluid into a gaseous state, local destruction and burning of the exposed area. Unlike the common scalpel the laser one both dissects tissues and is also able to preserve edges of small cuts, that is it can perform biological welding.

We should note such an effect of laser radiation as stimulation of the regenerative process too. Laser has unique and specific properties during its interaction with target tissues: being a damaging factor, it facilitates an actually total regeneration of the nerve trunk structures in future.

The advantage of the laser scalpel consists in a small injury of the operation because of an insignificant width of the cut with simultaneous coagulation of vessels and provision of absolute sterility. All the above factors result in shortening of the period of wound healing by two-three times. Results of the experiment are summarized in the Table 1.

\section{Conclusions}

It was for the first time that our experimental-morphological study revealed peculiarities of the nerve trunk regeneration in the puncture methods of destruction, which are most frequently used for treating facial pains, the above making possible the following conclusions:

- the use of alcoholization for treatment of trigeminal neuralgia is not sufficiently effective after its repeated application, it is traumatizing and causes the

Table 1

Peculiarities in the behaviour of animals, macro- and microscopic changes in the nerve, destruction and regeneration; efficacy of denervation

\begin{tabular}{|c|c|c|c|c|}
\hline \multirow{2}{*}{ Index } & \multicolumn{4}{|c|}{ Kind of destruction } \\
\hline & Alcoholization & Phenolization & Cryodestruction & Laser destruction \\
\hline $\begin{array}{l}\text { Behaviour of } \\
\text { animals }\end{array}$ & $\begin{array}{l}\text { Depressive, with } \\
\text { inhibition of food } \\
\text { and behavioural } \\
\text { reflexes during the } \\
\text { whole period of } \\
\text { follow-up }\end{array}$ & $\begin{array}{c}\text { Depressive. } \\
\text { Low activity up to } 30 \\
\text { days (the toxic effect of } \\
\text { phenol) }\end{array}$ & $\begin{array}{l}\text { Active from days } \\
\qquad 4-5\end{array}$ & $\begin{array}{l}\text { Active from days } \\
\qquad 3-4\end{array}$ \\
\hline $\begin{array}{l}\text { Trophic changes } \\
\text { on the extremity } \\
\text { skin, in the region } \\
\text { of the performed } \\
\text { manipulation }\end{array}$ & $\begin{array}{l}\text { Evident with suture } \\
\text { line disruptions; } \\
\text { suppuration, } \\
\text { ulceration, } \\
\text { cicatrization in the } \\
\text { perineural tissues }\end{array}$ & $\begin{array}{l}\text { Less evident, the general } \\
\text { toxic effect of phenol is } \\
\text { noted }\end{array}$ & None & None \\
\hline $\begin{array}{l}\text { Leukocyte } \\
\text { infiltration in the } \\
\text { perineural tissues } \\
\text { within early terms }\end{array}$ & Massive & Moderate & None & None \\
\hline $\begin{array}{l}\text { Cicatrical adhesion } \\
\text { in the perineural } \\
\text { tissues and nerve }\end{array}$ & $\begin{array}{c}\text { Evident in the } \\
\text { perineural tissues; } \\
\text { the state of } \\
\text { "neuropathy" in the } \\
\text { nerve }\end{array}$ & $\begin{array}{l}\text { Minimal in the perineural } \\
\text { tissues; a gradual slow } \\
\text { restoration of the nerve } \\
\text { structure, } \\
\text { without any cicatrix }\end{array}$ & $\begin{array}{l}\text { None in the } \\
\text { perineural tissues; } \\
\text { restoration of the } \\
\text { nerve structure is } \\
\text { delayed, without } \\
\text { any cicatrization }\end{array}$ & $\begin{array}{l}\text { None in the } \\
\text { perineural tissues; } \\
\text { a good restoration } \\
\text { of the nerve } \\
\text { structure, } \\
\text { without any cicatrix }\end{array}$ \\
\hline $\begin{array}{l}\text { Peculiarities in the } \\
\text { nerve structure } \\
\text { regeneration after } \\
\text { destruction }\end{array}$ & $\begin{array}{l}\text { Death of most } \\
\text { of Schwann cell } \\
\text { nuclei, large } \\
\text { balloon vacuolation } \\
\text { and destruction } \\
\text { of myelin, } \\
\text { disintegration of } \\
\text { axons; the changes } \\
\text { are irreversible: } \\
\text { the state of } \\
\text { "neuropathy", any } \\
\text { total regeneration is } \\
\text { impossible }\end{array}$ & $\begin{array}{l}\text { Destruction of myelin } \\
\text { and axons, preservation } \\
\text { of Schwann cell } \\
\text { nuclei, later there are } \\
\text { signs of small-bubble } \\
\text { vacuolation of myelin } \\
\text { coats (activation of } \\
\text { the endoplasmic } \\
\text { reticulum of Schwann } \\
\text { cells), restoration of } \\
\text { the endoneural tubes } \\
\text { and cell nuclei, and } \\
\text { regeneration of axons } \\
\text { (reversibility of changes) }\end{array}$ & $\begin{array}{l}\text { Disintegration of } \\
\text { axons and myelin, } \\
\text { preservation of the } \\
\text { endoneural tubes } \\
\text { and Schwann } \\
\text { cell nuclei, but } \\
\text { without activation } \\
\text { of the endoplasmic } \\
\text { reticulum with } \\
\text { preserved nuclei; a } \\
\text { total denervation; } \\
\text { regeneration of } \\
\text { axons is delayed }\end{array}$ & $\begin{array}{l}\text { Disintegration of } \\
\text { axons and myelin, } \\
\text { preservation of } \\
\text { Schwann cell } \\
\text { nuclei, later } \\
\text { there are signs } \\
\text { of activation of } \\
\text { the endoplasmic } \\
\text { reticulum, } \\
\text { preservation of the } \\
\text { endoneural tubes; } \\
\text { a total regeneration } \\
\text { of axons is possible }\end{array}$ \\
\hline $\begin{array}{l}\text { The result of } \\
\text { denervation }\end{array}$ & $\begin{array}{l}\text { Effective in } \\
\text { the beginning, } \\
\text { traumatizing }\end{array}$ & Satisfactory and good & Good & Good \\
\hline
\end{tabular}


state of "neuropathy" in the nerve trunk with gross cicatricial changes in the perineural tissues; the changes are irreversible; the above fact is clinically manifested by recurrences of pain in some cases (especially after a repeated use) in the form of uncontrolled neuropathic pain;

- the use of phenolization (as a variety of chemodestruction) for treatment of facial pains is less traumatizing and more effective, it does not cause the state of "neuropathy" in the nerve trunk and no cicatricial adhesion in the perineural tissues is evident; in view of the general toxic effect of phenol (poison) a more prudent approach to using this method of treatment in patients with severe forms of facial pains and meticulous dosing regimens are required;

- the use of crydestruction for treating facial pains is more effective and less traumatizing. Axons and myelin coats in the region of cryodestruction are destroyed and a good interruption of pathological pain impulses is provided. Microscopically, the endoneural tubes and Schwann cell nuclei are preserved. Restoration of the anatomical structure of nerve fibres is apparently delayed; no cicatricial adhesion in the perineural tissues is marked;

- the use of high-energy laser radiation in the infrared range with a wavelength of $980 \mathrm{~nm}$ in the continuous mode (with a radiation power of $3 \mathrm{~W}$ and a total radiation dose of $50 \mathrm{~J}$ ) makes it possible to create local foci of destruction in peripheral nerves with the minimal manifestation of perifocal changes. The manipulation makes it possible to interrupt a flow of pathological pain impulses by means of destruction of myelin coats and nerve axons with preservation of the nerve macroanatomy, Schwann cell nuclei and structure of the endoplasmic reticulum of Schwann cells, thereby providing favourable conditions for a total and anatomically correct restoration of the nerve trunk structure without any cicatrix that can be regarded as a manifestation of a total reparative regeneration. But the use of a laser radiation in the pulse mode with different parameters will provide a more precise influence on the region of pathology, it being necessary if this region is small or located in a close proximity to functionally important anatomical formations.

\section{References}

1. Karlova VA, editor. Neurology of the face. Moscow: Medicina Publ; 1991. 288 p. (in Russian)

2. Tsimbalyuk VI, Dmiterko IP, Sapon MA, et al. Ethiology, pathogenesis and neurochralgia licone neuralgia of the tripartite nerve (looking at the tutorial). Ukrainskij nejrohirurgichnij zhurnal [Ukrainian neurosurgical journal]. 2001;4:40-6. (in Ukrainian)

3. Sapon NA. Questions of the pathogenesis of trigeminal neuralgia (postulates, contradictions and new approaches). First post. Ukrainskij nejrohirurgichnij zhurnal [Ukrainian neurosurgical journal]. 2005;2:54-9. (in Ukrainian)

4. Sapon NA. Questions of the pathogenesis of trigeminal neuralgia (postulates, contradictions and new approaches).
The second message. Ukr. nejrohirurg. zhurnal [Ukr. neurosurg. journal]. 2005;4:72-6. (in Ukrainian)

5. Schloesser C. Zur Behandlung der Neuralgien durchAlkohol einspritzungen. Berl. Klin. Wschr. 1906, S. 82.

6. Kirschner M. Die Punktionstechnik und die Elektrokoagulation des Ganglion Gasseri. Uber "gezielte" Operationen. Arch. Klin. Chir. 1933; Bd.176: 581-620.

7. Jefferson A. Trigeminal neuralgia. J. Neurol. Neurosurg. Psychiatry. 1963; 26: 345-52.

8. Vasin NYa. On the method and results of the phenol blockade of the Gasser node with severe forms of facial pain. Zhurnal Voprosy nejrohirurgii im. N.N. Burdenko [Journal Questions neurosurgery named after N.N. Burdenko]. 1973;2:16-22. (in Russian)

9. Livshic LYa. Nevralgiya trojnichnogo nerva i ee lechenie metodom napravlennoj gidrotermicheskoj destrukcii chuvstvitel'nogo trigeminal'nogo koreshka [Neuralgia of the trigeminal nerve and its treatment by the method of directed hydrothermal destruction of the sensitive trigeminal root] [dissertation]. Saratov; 1968. 38 p. (in Russian)

10. Posokhov MF, Chernenkov VG, Pihtin OV, inventors; SI "Institute of Neurology, Psychiatry and Narcology of NAMS of Ukraine", assignee. Sposib likuvannya nevralgii trijchastogo nervu [Method of treatment neuralgia of the trigeminal nerve]. Patent 69236 Ukraine, МПК A61B 18/02 No. u201111451; September 28, 2011; 04/25/2012, bul. № 8/2012. (in Ukrainian)

11. Tsymbalyuk VI, Posohov NF, Sapon NA, et al. Cryodestruction of the sensitive root in the treatment of severe forms of trigeminal neuralgia. Byulleten' Ukrainskoj Associacii Nejrohirurgov [Bulletin of the Ukrainian Association of Neurosurgeons]. 1997;3:14-6. (in Russian)

12. Prodan AI, Bengus LM, Sirenko AA. The morphology of the sciatic nerve after local cryotherapy. Ortopediya, travmatologiya i protezirovanie [Orthopedics, traumatology and prosthetics]. 2010;2:66-72. (in Russian)

13. Cosman ER, Nashold BS, Overmann-Levit J. Theoretical aspects of the radio entry zone. Neurosurgery. 1984;15:945-50.

14. Posohov MF, Tsymbalyuk VI, Pihtin OV, Posohov SM, Gorbunov OV, Korobov AM, Holin VV, inventors; SI "Institute of Neurology, Psychiatry and Narcology of the NAMS of Ukraine”, assignee. Sposib likuvannya nevralgii trijchastogo nervu metodom lazernoi nejrotomii periferichnih gilok [Method of treatment neuralgia of the trigeminal nerve by the method of laser neurotomy of peripheral branches. Patent 76598 Ukraine, MПК A61N 5/06. No. u201207521; 06/19/2012; 01/10/2013 bulletin No. 1/2013. (in Ukrainian)

15. Posohov NF, Tsymbalyuk VI, Gorbunov OV, et al. Experimental and morphological study of the methods of alcohol, cryo and laser destruction of the nerve trunk. Materialy XXXIX Mezhdunarodnoj nauchno-prakticheskoj konferencii. Primenenie lazerov v medicine i biologii [Proceedings of the XXXIX International Scientific and Practical Conference. The use of lasers in medicine and biology]; 2013 May 22-24; Kharkov. Kharkov; 2013; p. 126-7. (in Russian)

16. Kozel AI. New minimally invasive laser technologies in the practice of the Chelyabinsk State Institute of Laser Surgery. Izvestiya Chelyabinskogo nauchnogo centra [Proceedings of the Chelyabinsk Scientific Center]. 2001;2(11):112-6. (in Russian)

17. Ismagilova ST. Dinamika morfologicheskih izmenenij trojnichnogo nerva pri destrukcii ego chuvstvitel'nogo 
koreshka vysokointensivnym lazernym izlucheniem (ehksperimental'noe issledovanie) [The dynamics of the morphological changes of the trigeminal nerve during the destruction of its sensitive root by high-intensity laser radiation (experimental study)] [dissertation]. Chelyabinsk; 1997. 22 p. (in Russian)

18. Burchiel K, editor. Wilkins RH. Trigeminal neuralgia: history, with emphasis on surgical treatment. Surgical Management of Pain. New York: Thieme; 2002. p. 288-303.

19. Han KR, Chae YJ, Lee JD, et al. Trigeminal neuralgia: long-term clinical effectiveness on pain. International Journal of Medical Sciences. 2017;14(1):29-36.

20. Shengelia NS. Kliniko-ehksperimental'noe obosnovanie metoda alkogolizacii pri nevralgii trojnichnogo nerva (Kliniko-morfologicheskoe issledovanie) [Clinical and experimental substantiation of the method of alcoholism in trigeminal neuralgia (Clinical and morphological study)]. Tbilisi: Mecniereba Publ; 1981. 132 p. (in Russian)

21. Megdyatov RS. Nevralgiya trojnichnogo nerva [Neuralgia of the trigeminal nerve]. Moscow: Medicina Publ; 1999. 144 p. (in Russian)

22. Savickaya ON, Dzugaeva SB. About neuralgia (neuritis) of the trigeminal nerve. Zhurnal nevropatologii i psihiatrii im. S.S. Korsakova [SS Korsakov Journal of Neuropathology and Psychiatry]. 1971;5:690-4. (in Russian)

23. Wood KM. The use of phenol as a neurolytic agent. A review. Pain 1978;5:205-29.

24. Hernández-Santos JR, Plancarte R, Oliva S, et al. Bloqueo de ganglio de gasser con glicerol versus fenol intragasseriano para neuralgia trigeminal. Rev. Soc. Esp. Dolor. 1999;6:269-76.

25. Laks A, Nurmiste A. The introduction of glycerol into the trigeminal cistern in the treatment of the trigeminal nerve. Aktual'nye voprosy nevrologii i nejrohirurgii. Materialy III siezda nevrologov i nejrohirurgov Ehstonskoj SSR [Topical issues of neurology and neurosurgery. Materials of the III congress of neurologists and neurosurgeons of the Estonian SSR]. 1989;T.1:104-6. (in Russian)

26. Livshits A. Directional hydrothermal destruction of the sensitive root of the trigeminal nerve as a method for treating trigeminal neuralgia. Voprosy nejrohirurgii [Neurosurgery issues]. 1965;4:47-52. (in Russian)

27. Berezhnoj BI. Experience with hydrothermal destruction of sensitive roots of the Gasser's node in trigeminal neuralgia. Materialy 1 konferencii nejrohirurgov Respubliki Krym [Proceedings of the 1st conference of neurosurgeons of the Republic of Crimea]; Kerch; 1995. p. 61-63. (in Russian)

28. Meglio M, Cioni B. Percutaneous procedures for trigeminal neuralgia: Microcompression versus radiofrequency thermocoagulation. Personal experience. Pain. 1989;38(1):9-16.

29. Prodan OI, Bengus LM, Sirenko OA, et al. Morphological images of the fusion nerve using your ears for electrical coagulation (experimental further). Naukovij visnik Uzh- gorods'kogo Un-tu [Science Bulletin of Uzhhorod Uni]. 2007;32:149-52. (in Ukrainian)

30. Bengus LM, Prodan AI, Sirenko AA. Characteristics of the morphological changes of the sciatic nerve during its damage by electrocoagulation and cryotherapy. Problemi osteologii [Problems of Osteology]. 2008;10(1-2): 59-62. (in Russian)

31. TroyanVV, Glebov MA. Comparative results of surgical methods for treating trigeminal neuralgia. Nejrohirurgiya [Neurosurgery]. 2007;1:25-8. (in Russian)

32. Mogila VV, Litvinenko SV. The current state of the problem of treating trigeminal neuralgia. Nejrohirurgiya [Neurosurgery]. 2002;4:12-4. (in Russian)

33. Sipityj VI, Posohov NF, Pyatikop VA. Kriohirurgicheskoe lechenie tyazhelyh form nevralgii trojnichnogo nerva [Cryosurgical treatment of severe forms of trigeminal neuralgia]. Kharkov: Osnova Publ; 1995. 112 p. (in Russian)

34. Murinec-Markevich BN, Sipityj VI, Krasnikov AR, et al. Neurosurgical cryoprobe for treating trigeminal neuralgia Preprint Fiziko-tekhnicheskogo instituta nizkih temperatur Akademii nauk USSR [Preprint of the Physico-Technical Institute of Low Temperatures of the Academy of Sciences of the Ukrainian SSR]. Kharkov; 1986; 35. 7 p. (in Russian)

35. Ismagilova ST, Kozel' A.I. Surgical treatment of trigeminal neuralgia with high-intensity laser radiation. Materialy II siezda nejrohirurgov Rossijskoj Federacii [Proceedings of the II Congress of Neurosurgeons of the Russian Federation]; 1998 June 16-19; Nizhny Novgorod. St. Petersburg; 1998. p. 203. (in Russian)

36. Matkivskij RM. Ultrastructure organ of the synergic nerve. Klinichna anatomiya ta operativna hirurgiya [Clinical anatomy and operative surgery]. 2007;6(1):16-9. (in Ukrainian)

37. Hem A, Kormak D. Gistologiya [Histology]. Moscow: Mir Publ, 1983. V. 3; 293 p. (in Russian)

38. Cherepnev GV, Chelyshev YuA. . Molecular and cellular aspects of pharmacological stimulation of nerve regeneration. Eksperimentalnaya i klinicheskaya farmakologiya [Experimental and clinical pharmacology]. 2001;64(3):67-71. (in Russian)

39. Schudlo NA. Analysis of myeloarchitectonics of regenerating peripheral nerve of experimental animals in remote periods after microsurgical suture and electrosmulation. Annaly hirurgii [Annals of Surgery]. 2006;3:58-61. (in Russian)

40. Turgut M, Uyanikgil Y, Baka M. et al. 40. Pinealectomy exaggerates and melatonin treatment suppresses neuroma formation of transected sciatic nerve in rats: gross morphological, histological and stereological analysis. J. Pineal. Res. 2005;38(4):R.284-91.

41. Bagrij MM, Dibrova VA., editors. Metodiki morfologichnih doslidzhen: monografiya [Methods of morphological research: monograph]. Vinnitsa: Nova Kniga Publ, 2016. 328 p. (in Ukrainian) 